Research Article

\title{
Synergistic Anti-oxidant Property of Seed Extracts of Trigonella foenum-graecum, Nigella sativa and Linum usitatissimum
}

\author{
Kavitha G Singh*, Thilagavathy A, Meena V, Jahnavi R, Hiba Basheer, Vishnupriya M, Kriti Bhadani, Umme Umaima \\ Mount Carmel College, Autonomous, Bengaluru, Karnataka, India. \\ *Corresponding author's E-mail: kavi182@yahoo.co.in
}

Received: 05-09-2020; Revised: 18-11-2020; Accepted: 27-11-2020; Published on: 15-12-2020.

\begin{abstract}
The present study was conducted to investigate the anti-oxidant properties of different crude seed extracts of Trigonella foenumgraecum, Nigella sativa, Linum usitatissimum individually and mixture of these seeds. The extracts from these seeds were obtained using different solvents - water, methanol and chloroform. Flavonoid and phenolic content of these crude seeds extracts were evaluated quantitatively. Percentage of inhibition of lipid peroxidation and peroxide value was also determined. This study shows that these seed extracts can scavenge free radicals to an appreciable level thereby decreasing the oxidative stress, the anti-oxidant property could be due to phenols and flavonoids present in the seed sample. It was observed that methanolic extract of seed mix (Fenugreek, Black cumin and Flax) had higher flavonoid content compared to other seed extracts. Methanolic extract of seed mix could inhibit oxidation of lipid efficiently compared to other extracts. Lower peroxide value was obtained when treated with aqueous and methanolic extract of seed mix, thereby by acting as a good anti-oxidant. This study shows that methanolic extract of seed mix has a better anti-oxidant property compared to other extracts.
\end{abstract}

Keywords: Anti-oxidant, phenols, flavonoids, lipid peroxidation.

QUICK RESPONSE CODE $\rightarrow$

DOI:

10.47583/ijpsrr.2020.v65i02.020

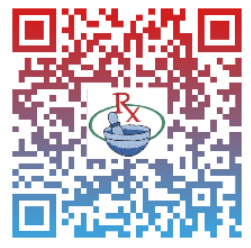

DOI link: http://dx.doi.org/10.47583/ijpsrr.2020.v65i02.020

\section{INTRODUCTION}

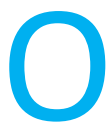

xidative stress and an escalation in the levels of free radicals are amongst the leading central markers associated with numerous progressive pathological conditions, including neurological disorder, cancer, aging, and endocrine illness. Numerous abiotic stresses lead to the overproduction of reactive oxygen species (ROS) in plants and animals which are highly reactive and detrimental causing damage to proteins, lipids, carbohydrates and DNA thus leads to oxidative stress. This oxidative stress causes damage to tissues and results in large number of illnesses. ${ }^{1}$

The term "ROS" includes all unstable metabolites of molecular oxygen $\left(\mathrm{O}_{2}\right)$ that have higher reactivity than $\mathrm{O}_{2}$ like superoxide radical $\left(\mathrm{O}_{2}{ }^{\circ}\right)$ and hydroxyl radical $\left(\mathrm{HO}^{*}\right)$ and non-radical molecules like hydrogen peroxide $\left(\mathrm{H}_{2} \mathrm{O}_{2}\right)$. These ROS are generated as byproduct of normal aerobic metabolism, but their level increases under stress which proves to be a basic health hazard. Mitochondrion is the major cell organelle responsible for ROS production. ${ }^{2,3}$ It generates ATP through a series of oxidative phosphorylation processes. During this process, one- or two-electron reductions instead of four electron reductions of $\mathrm{O}_{2}$ can occur, leading to the formation of $\mathrm{O}_{2} \cdot$ or $\mathrm{H}_{2} \mathrm{O}_{2}$, and these species can be converted to other ROS. Other sources of ROS may be reactions involving peroxisomal oxidases, ${ }^{3}$ cytochrome $P$-450 enzymes, ${ }^{4}$ NAD (P)H oxidases, ${ }^{5}$ or xanthine oxidase. ${ }^{6}$

An antioxidant can be broadly defined as any substance that delays or inhibits oxidative damage to a target molecule. ${ }^{7}$ The main role of anti-oxidant is to scavenge the free radicals. Antioxidant compounds like phenolic acids, polyphenols and flavonoids scavenge free radicals such as peroxide, hydroperoxide or lipid peroxyl and thus inhibit the oxidative mechanisms that lead to degenerative diseases. ${ }^{8}$ Herbal plants have been considered as good antioxidants since ancient times.

Antioxidants overcome the consequences of ROS and thus help in preventing diseases. Antioxidants can be natural or synthetic. Fruits, vegetables and spices are natural source of anti-oxidant which can be taken through diet. There are also specific synthetic antioxidants like BHT and BHA that inhibit oxidation. Nonetheless, these synthetic antioxidants have now been reported to be critical to humans so the search for non-toxic antioxidants have intensified in the recent years. At present, there has been a growing concern in the therapeutic option of medicinal plants as natural antioxidants. Synthetic anti-oxidants can be substituted with natural anti-oxidant in food, cosmetic and pharmaceutical industries due to low cost and no adverse effects. Many naturally occurring anti-oxidants found in plant source scavenge free radicals. Active antioxidant activities have been found in berries, cherries, citrus fruits, prunes and olives. Herbal plants have been considered as good antioxidants since ancient times. ${ }^{1}$ 
Trigonella foenum-graecum (Fabaceae) is an annual plant, which is grown in most of the countries. ${ }^{9}$ Fenugreek is a forage and legume crop. Fenugreek seed is pleasantly bitter, slightly sweet. Seeds are used to flavour many foods. ${ }^{10}$ Endosperm of fenugreek seed as highest amount of saponin and protein content, husk contains higher amount total polyphenols. ${ }^{11}$ Fenugreek seed has wide application, therefore extensively used in various fields like pharmaceutical, nutraceuticals etc. It is effective in the treatment of diabetes, hyperglycaemia (thyroxine-induced type) and hypercholesterolemia. ${ }^{12}$ Fenugreek is recommended as a medicine in dysmenorrheal, postmenopausal symptoms and promotion of lactation. It is used orally as a substitute for insulin to decrease blood glucose level. ${ }^{13}$ Fenugreek fiber helps in increasing satiety and reducing intake of fat. ${ }^{14,15,16}$ It has a role in cleansing the blood, detoxing body, lymphatic cleansing activity, maintains mucous conditions in the body, majorly in lungs to clear congestion. ${ }^{17}$ It is also used as tonic for weakness and treatment for edema. ${ }^{18}$ It selectively reduces LDL, VLDL and increases HDL cholesterol. ${ }^{19}$ Studies show that it decreases oxidative damage. ${ }^{20}$ It is also used as herbal medicine to treat diabetes, fertility related problems, to stimulate lactation, microbial infections, cancer, hypercholesterolemia, parasitic diseases etc. ${ }^{21}$ Fenugreek can be recommended and must be taken as a part of our daily diet as its liberal use is safe and has various health benefits.

Nigella sativa is an annual crop, seeds are ovate, tetrangular, angles sharp, acute and more tapering at the end. Macroscopically, seeds are black externally and white inside, odour slightly aromatic and taste bitter. ${ }^{22}$ It is used as treatment for wide range of disorders like respiratory, digestive, excretory etc. ${ }^{23,24}$ Nigella sativa (Ranunculaceae) is an extensively used medicinal plant all over the world. ${ }^{22}$ Thymoquinone found in Nigella sativa has antiinflammatory, anti-diabetic, anti-cancer, anti-bacterial, anti-hypertensive properties. ${ }^{25,}{ }^{26}$ It helps to reduce the symptoms caused due to asthma and allergic rhinitis. ${ }^{22,} 27$ Essential oil of this seed act as anti-oxidant. ${ }^{28}$ It was found that seed powder decreased LDL and increased HDL cholesterol. ${ }^{29}$ It reduces toxic effect caused by chemicals, thereby protecting liver and kidney. ${ }^{30}$ The maximal nutritional value of black cumin can be linked to the presence of considerable amount of vegetable protein, fibre and minerals, and vitamins. Among various amino acids identified, glutamate, arginine, and aspartate while cysteine and methionine were the major and minor amino acids, respectively. ${ }^{31}$

Linum usitatissimum (Lineaceae), is a blue flowering annual herb that produces small flat reddish brown coloured seed with crispy texture and nutty taste. 32,33 Almost all parts of flaxseed plant are utilized for various purposes. Flaxseed contains oil which after refining is used for edible purpose. ${ }^{34}$ Currently, it is cultivated in more than fifty countries. ${ }^{35}$ It was a native crop of India and a staple food crop. It is used for various medicinal purposes. ${ }^{36}$ It has potential health benefits associated with its biologically active components-Alpha linolenic acid, lignan-Secoisolariciresinol diglycoside (SDG) and dietary fibre. ${ }^{37}$

Flaxseed has alpha-linolenic acid, lignans, high quality protein, soluble fibre and phenolic compounds. ${ }^{35}$ Growing environment, genetics and processing conditions affect the chemical compositions of the seeds. ${ }^{32}$ The lipid content of flaxseed varies from 37 to $45 \mathrm{~g} / 100 \mathrm{~g}$ of the seed. ${ }^{38,} 39,32$ Flaxseed oil contains $98 \%$ triacylglycerol, phospholipids and $0.1 \%$ free fatty acids. ${ }^{40}$ On an average it contains $21 \%$ protein. Majority of the protein is concentrated in the cotyledons. ${ }^{41}$ Amino acid profile and nutritional value of flaxseeds are comparable to that of soya proteins. ${ }^{42,43}$ The processing conditions, dehusking and defatting affect the protein content. The defatted and dehusked meals have high protein content. ${ }^{44,45}$ Flaxseed proteins exhibit antifungal properties against Alternaria solani, Candida albicans and Aspergillus flavus. ${ }^{46,47}$

Phenolic compounds are responsible for anti-oxidant and anticancer properties. Flaxseeds have three different types of phenolic compounds-phenolic acids, flavonoids and lignans. It contains highest amount of potassium, intake of high potassium decreases blood platelet aggregation, free radicals in blood and stroke incidence. ${ }^{38}$ Vitamin $E$ is present as $\gamma$-tocopherol, which is an antioxidant providing protection to cell proteins and fat from oxidation. ${ }^{48,32}$

\section{MATERIALS AND METHODS}

\section{Plant source}

Trigonella foenum-graecum, Nigella sativa and Linum usitatissimum seeds were brought from Departmental store in Vasanthnagar.

\section{Sample preparation}

Seed samples were ground to fine powder and $10 \%$ aqueous, methanol and chloroform extracts of Trigonella foenum-graecum, Nigella sativa, Linum usitatissimum and mixture of these powdered seeds were prepared by using magnetic stirrer. The seed extracts were centrifuged and supernatant obtained was used for further assays.

\section{Quantitative determination of total flavonoid content}

The flavonoid content of the crude seed extract was determined according to the method proposed by Chang et al., $2002^{49}$ with a few modifications. Different concentration of quercetin $(2-10 \mu \mathrm{g})$ was used as standard. The solutions were made up to $2 \mathrm{ml}$ with methanol. $2 \mathrm{ml}$ of methanol was taken in a fresh test tube as blank. To another set of test tubes $0.1 \mathrm{ml}$ of extracts were taken individually and made up to $2 \mathrm{ml}$ with methanol. To this reaction mixture $1 \mathrm{ml}$ of $10 \%$ aluminium chloride was added followed by $0.1 \mathrm{ml}$ of $1 \mathrm{M}$ potassium acetate and 2.8 $\mathrm{ml}$ of distilled water. After addition of the reagents, the tubes were incubated for 30 minutes at room temperature. After incubation, the absorbance of the reaction mixture was measured at $415 \mathrm{~nm}$. The flavonoid 
content of crude extract was measured as mg quercetin equivalent/g of extract.

\section{Quantitative determination of total phenolic content}

The total phenolic content of the crude extract was determined according to the method described by Sarbjot Kaur and Poonam Mondal (2014). ${ }^{50} 0.2$ to $1.0 \mathrm{ml}$ aliquots of standard gallic acid solution $(1 \mathrm{mg} / \mathrm{ml})$ was pipetted out into different test tubes. The volume in each test tube was made upto $1 \mathrm{ml}$ using distilled water. For blank, $1 \mathrm{ml}$ of distilled water was taken. For test samples, $0.1 \mathrm{ml}$ of the extract was taken and made upto $1 \mathrm{ml}$ with distilled water. To all the tubes $0.5 \mathrm{ml}$ of FC reagent was added and incubated for 5 minutes at room temperature. After incubation, $1.5 \mathrm{ml}$ of $20 \%$ sodium bicarbonate was added in order to produce alkaline medium. Then $7 \mathrm{ml}$ of distilled water was added. Absorbance was measured at $750 \mathrm{~nm}$ spectrophotometrically. The total phenolic content of the crude extract was expressed as gallic acid equivalent in milligrams/g of extract.

\section{Determination of peroxide value}

Peroxide value was determined titrimetrically using sodium thiosulphate as titrant. $5 \mathrm{~g}$ of oil was taken in a conical flask and $15 \mathrm{ml}$ of acetic acid - chloroform mixture was added and swirled till it dissolved. $0.25 \mathrm{ml}$ of saturated $\mathrm{KI}$ was added and kept aside for 1 minute with occasional shaking. Then $15 \mathrm{ml}$ of distilled water was added followed by 5 drops of starch solution. Mixture was titrated against $0.1 \mathrm{~N}$ sodium thiosulphate till blue colour disappeared. For the test samples, to $5 \mathrm{~g}$ of oil, $5 \mathrm{ml}$ of extract was added and incubated for 5 minutes and the same method was followed.

Peroxide value was determined by following formula

Peroxide value $=($ Titre value $\times 0.1 \times 1000) / 5$

\section{MDA Assay}

The assay was carried by pipetting out $0.4 \mathrm{ml}$ of serum to all test tubes followed by addition of $3 \mu \mathrm{l}$ of lead acetate (3ppm) and $0.6 \mathrm{ml}$ of extract. Control was prepared by pipetting $0.4 \mathrm{ml}$ of serum and $3 \mu \mathrm{l}$ of lead acetate without the extract. The mixture was incubated at $37 \stackrel{\circ}{\circ}$ in shaker for 120 minutes. After the mixture was incubated $0.5 \mathrm{ml}$ of the above mixture was made upto $1 \mathrm{ml}$ with distilled water, followed by addition of $5 \mathrm{ml}$ of glacial acetic acid and 0.05 $\mathrm{ml}$ of TBA. The samples were kept in boiling water bath for $45 \mathrm{~min}$ and were allowed to cool. The cooled solution was further treated by addition of $0.05 \mathrm{ml} \mathrm{HCl}$. The optical density was determined spectrophotometrically at $535 \mathrm{~nm}$.

\section{RESULTS AND DISCUSSION}

Anti-oxidant property was determined in different extracts of Trigonella foenum-graecum, Nigella sativa, Linum usitatissimum and mixture of these powdered seeds by different assays.

\section{Determination of flavonoid content}

Flavonoids are used for prevention and cure of diseases associated with free radicals. They are found to have defensive effect against bacterial and viral infections and diseases such as cardiovascular ailments, malignancies and other age related illnesses. Flavonoids also have antihistamine, memory and even mood-enhancing properties. It has anti-oxidative, anti-inflammatory, antimutagenic and anti-carcinogenic properties and also has the capacity to modulate cellular enzyme function. It also lowers cardiovascular mortality rate. ${ }^{51}$

The total flavonoid content was calculated using standard curve of quercetin ( $\mathrm{y}=0.049 \mathrm{x}-0.009 ; R^{2}=0.991$ ) and expressed as quercetin equivalent per gram of plant extract.

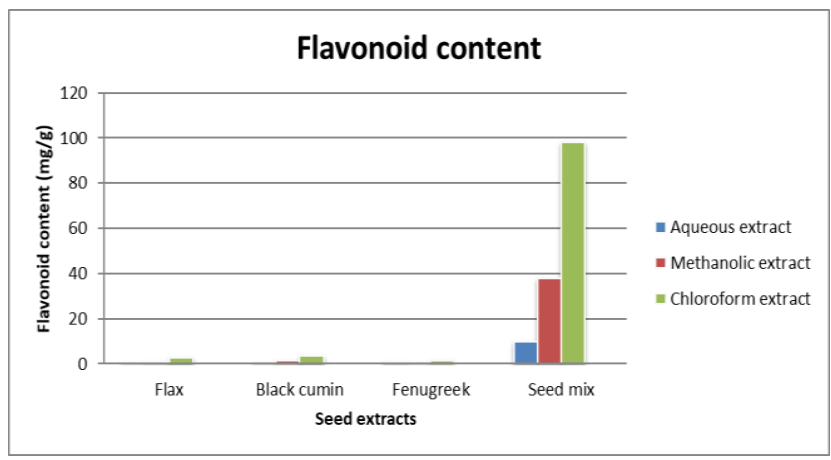

Figure 1: Flavonoid content

It was found that flavonoid content was higher in methanolic extract of seed mix (37.985 mg QE/g), followed by aqueous extract of seed mix (9.968 mg QE/g). Higher values were observed in chloroform extract due to turbidity therefore, it was not taken into consideration

\section{Determination of phenol content}

Phenolic compounds play a major role in defence activity against plant pathogens and abiotic stressors. ${ }^{52}$ They reduce rate of oxidation of organic matter by transferring hydrogen atoms to free radicals which leads to termination of free radical chain reaction. ${ }^{53}$ Antioxidants delays or prevent oxidation of lipids, proteins, nucleic acid. ${ }^{54}$

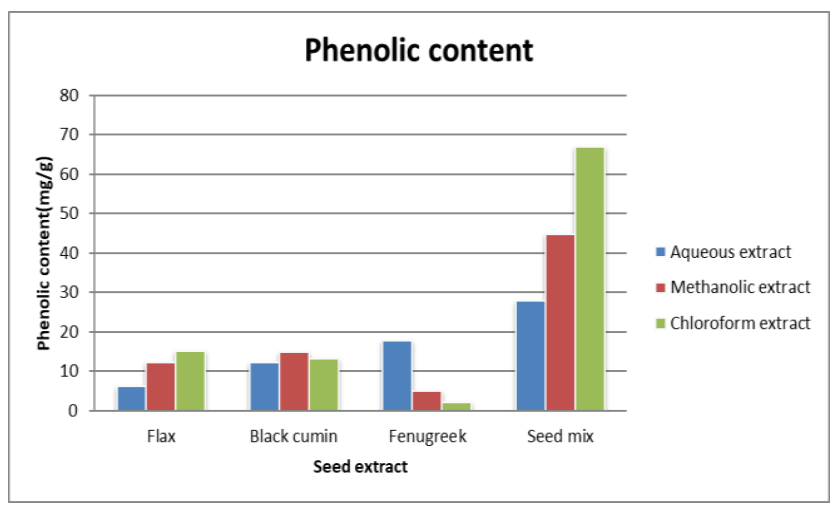

Figure 2: Standard plot for total phenolic content.

The total phenolic content was calculated by the standard curve of gallic acid ( $y=0.25 x ; R^{2}=1$ ) as shown in the figure 5. 
High amount of phenolic was shown by methanolic extract of seed mix (44.79 GAE/g) followed by aqueous extract of seed $\operatorname{mix}(27.96 \mathrm{GAE} \mathrm{mg/g}$ ). Higher values were also observed in chloroform extract which was due to turbidity therefore, it was not taken into consideration

\section{Determination of inhibition of lipid peroxidation}

Lipid peroxidation has been treated as a major mechanism of cellular injury in many biological systems of plant and animal origin. The mechanism comprises of a process where in the unsaturated lipids are oxidized to produce additional radical species as well as toxic by-products that can be lethal to the host system. Polyunsaturated lipids are exceptionally prone to this type of damage when in an oxidizing environment and they can react to form lipid peroxides.

Lipid peroxides are themselves unstable, and can undergo additional decomposition to form a complex series of compounds consisting of reactive carbonyl compounds. Polyunsaturated fatty acid peroxides further reacts to form malondialdehyde. Malondialdehyde (MDA) is the most commonly used biomarker of oxidative stress in a number of illnesses such as cancer, Alzehimer's, Parkinson's disease etc.

An MDA -TBA complex is formed on reaction with malondialdehyde and TBA which is read at $530 \mathrm{~nm}$.

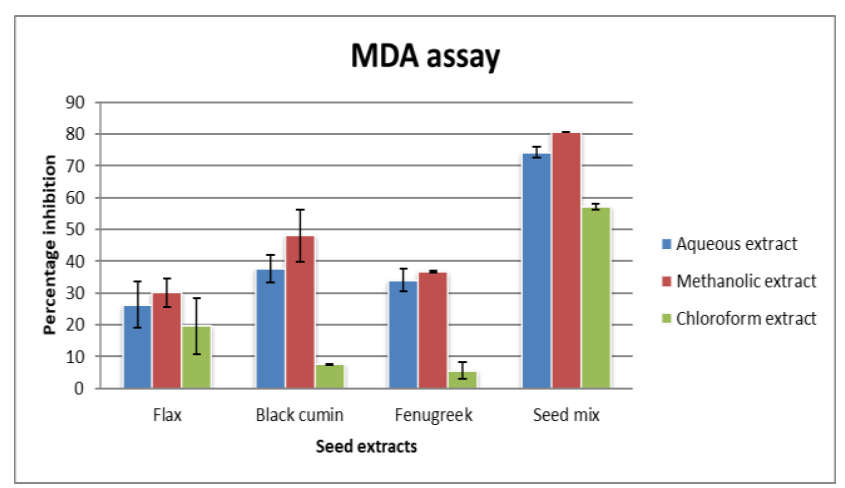

Figure 3: Estimation of percentage inhibition of lipid peroxidation of seed extracts

The serum along with the lead acetate caused free radical production or lipid peroxidation. The seed samples that were used reduced the oxidation process, thereby acting as excellent antioxidants. From the above bar graph, it can be observed that, the methanolic extract of seed mix showed the highest percentage inhibition i.e., it could inhibit the lipid to a greater extent compared to the other extracts. It was also noted that the aqueous and methanolic extractions of the seed samples showed a better inhibition activity when compared to that of the chloroform extract.

\section{Determination of peroxide value}

Peroxide value was performed to determine the amount of peroxides present in the sample of fat, which is expressed as milli-equivalents of peroxide per $1000 \mathrm{~g}$ of material. The fat sample in acetic acid chloroform medium, is treated with an aqueous solution of potassium iodide. The liberated iodide is determined by titrating it against standard sodium thiosulphate solution.

Unsaturated free fatty acids react with oxygen and form peroxides, that lead to production of smelly, volatile substances. Peroxide value is the most widely used indicator of fat oxidation.

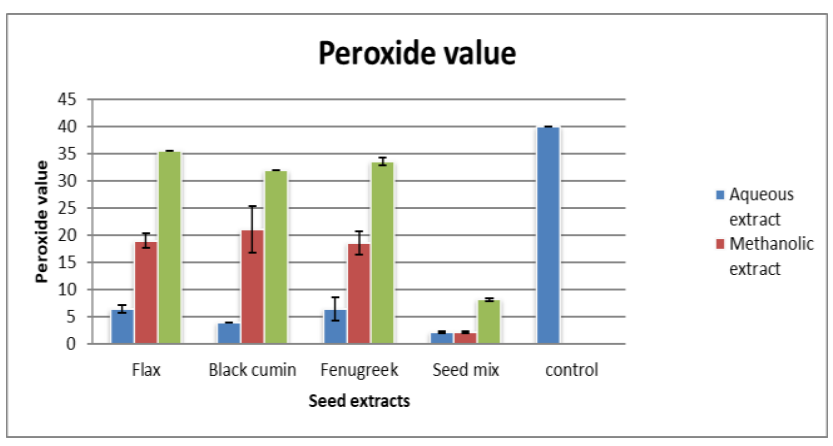

Figure 4: Determination of peroxide value

A lower peroxide value indicates good quality of oil and good preservation status. It was observed that all of these extracts decreased the peroxide value of oil. Aqueous and methanolic extracts of seed mix had a better effect on oil compared to other extracts in reducing the peroxide value. Peroxides can damage cell membrane, lead to hemolysis by rupturing $\mathrm{RBC}^{\prime} \mathrm{s},{ }^{55}$ mutation, cancer $^{56}$ etc.

\section{CONCLUSION}

According to the present study, it was concluded that the inhibition of lipid peroxidation activity of the seed mix was improved via synergistic interactions .It was also able to reduce the peroxide values of oil to a greater extent when compared to the individual seed extracts, this may be due to a higher content of phenols and flavonoids. Among the solvents, methanol showed the better performance as compared to water and chloroform.

\section{REFERENCES}

1. Sindhi V, Gupta V, Sharma K, Bhatnagar S, Kumari R, Dhaka N, Potential applications of antioxidants - A review . Journal of Pharmacy Research, 7(9), 2013, $828-835$.

2. Liu Y, Fiskum G, Schubert D, "Generation of reactive oxygen species by the mitochondrial electron transport chain", Journal of Neurochemistry, 80(5), 2002, 780-787.

3. Inoue M, Sato EF, Nishikawa M, Park A, Kira Y, Imada I, Utsumi K, "Mitochondrial generation of reactive oxygen species and its role in aerobic life," Current Medicinal Chemistry, 10(23), 2003, pp. 2495-2505.

3. Dvorakova M, Höhler B, Vollerthun R, Fischbach T, Kummer W, "Macrophages: a major source of cytochrome b558 in the rat carotid body," Brain Research, 852(2), 2000, pp. 349-354.

4. Geiszt M, Kapus A, Német K, Farkas L, Ligeti E, "Regulation of capacitative $\mathrm{Ca}^{2+}$ influx in human neutrophil granulocytes. Alterations in chronic granulomatous disease," Journal of Biological Chemistry, 272(42), 1997, pp. 26471-26478.

5. Cheng G, Cao Z, Xu X, Meir EGV, Lambeth JD, "Homologs of gp91phox: cloning and tissue expression of Nox3, Nox4, and Nox5," Gene, 269(1-2), 2001, 131-140.

6. Dorsam G, Taher MM, Valerie KC, Kuemmerle NB, Chan JC, Franson RC, (2000). "Diphenyleneiodium chloride blocks inflammatory cytokine- 
induced up-regulation of group IIA phospholipase A (2) in rat mesangial cells," Journal of Pharmacology and Experimental Therapeutics, 292(1), 2000, 271-279.

7. Yamagishi S, Matsui T, Pharmacol Res., "Nitric oxide, a janus-faced therapeutic target for diabetic microangiopathy-Friend or foe", 2011.

8. Wu YY, Li W, Xu Y, Jin EH, Tu YY J Zhejiang Univ Sci B, "Evaluation of the antioxidant effects of four main theaflavin derivatives through chemiluminescence and DNA damage analyses", 2011.

9. Parthasarathy VA, Kandinnan K, Srinivasan, V(ed.), "Fenugreek". Organic Spices. New India Publishing Agencies.2008, P.694.

10. Betty RI, The many healing virtues of fenugreek, Spice India, 1, 2008, 17-19.

11. Naidu MM, Shyamala BN, Naik PJ, Sulochanamma G, Srinivas $P$, Chemical composition and antioxidant activity of the husk and endosperm of fenugreek seeds. Food Science Technology, 44, 2010, 451456.

12. Zandi P, Basu SK, Khatibani LB, Balogun MO, Aremu MO, Sharma M, Kumar A, Sengupta R, Li X, Li Y, Tashi S, Hedi A, William Cetzal-Ix, Fenugreek (Trigonella foenum-graecum L.) seed: a review of physiological and biochemical properties and their genetic improvement, Acta Physiologiae Plantarum, 37, 2015, Article number: 1714.

13. Madar Z, Stark AH, New legume sources as therapeuctic agents, Brit. J. Nutr, 88, 2002, pp. S287-S292.

14. Mathern JR, Raatz SK, Thomas W, Slavin JL, Effect of fenugreek fiber on satiety, blood glucose and insulin response and energy intake in obese subjects, Phytotherapy Research, 23(11), 2009, 1543-8.

15. Chevassus H, Molinier N, Costa F, Galtier F, Renard E, Petit P, A fenugreek seed extract selectively reduces spontaneous fat consumption in healthy volunteers, Eur J Clin Pharmacol, 65(12), 2009, 1175-8.

16. Chevassus, H, Gaillard JB, Farret, A, Costa, F, Gabillaud I, Mas E, Dupuy AM, Michel F, Cantié C, Renard E, Galtier F, Petit P, A fenugreek seed extract selectively reduces spontaneous fat intake in overweight subjects, Eur J Clin Pharmacol, 66(5), 2010, 449-55.

17. Anonymous, Fenugreek, Herbs are special, 2013.

18. Yoshikawa M, Murakami T, Komatsu H, et al., Medicinal foodstuffs, IV, Fenugreek seed, (1): structures of trigoneosides la, Ib, Ila, IIb, IIla, and IIIb, new furostanol saponins from the seeds of Indian Trigonella foenumgraecum L. Chem Pharm Bull (Tokyo), 45, 1997, 81-87.

19. Al-Habori M, Raman A, Antidiabetic and hypocholestrolaemic effects of fenugreek, Phytotherapy research, 12(4), 1998, 233-242.

20. Ravikumar P, Anuradha CV, Effect of fenugreek seeds on blood lipid peroxidation and antioxidants in diabetic rats, Phytotherapy Research, 13, 1999, 1-5.

21. Wani SA, Kumar $P$, Fenugreek: $A$ review on its nutraceutical properties and utilization in various food product, Journal of the Saudi Society of Agricultural Sciences, 17(2), 2018, 97-106.

22. Ahmad A, Husain A, Mujeeb M, Khan SA, Najmi AK, Nasir Al, Siddique, Zoheir A, Damanhouri, Anwar F, A review on therapeutic potential of Nigella sativa: A miracle herb. Asian Pacific Journal of Tropical Biomedicine, 3(5), 2013, 337-352.

23. Sharma PC, Yelne MB, Dennis TJ, Database on medicinal plants used in Ayurveda, New Delhi, 2005, pp. 420-440.

24. Goreja WG, Black seed: nature's miracle remedy, New York, NY: Amazing Herbs Press, 2003.

25.Tavakkoli A, Ahmadi A, Razavi BM, Hosseinzadeh H, Black seed and its constituent thymoquinone as an antidote or a protective agent against natural or chemical toxicities, Iran J Pharm Res, 16(Suppl), 2017, 2-23.

26.Fallah huseini H, Amini M, Mohtashami R, Ghamarchehre M, Sadeqhi Z, Kianbhakt S, Husienini AF, Blood pressure lowering effect of Nigella sativa L. seed oil in healthy volunteers: a randomized, double-blind, placebo-controlled clinical trial, Phytother Res, 27(12), 2013, 1849-53.
27.Nikakhlagh S, Rahim F, Aryani FH, Syahpoush A, Brougerdnya MG, Saki $\mathrm{N}$, Herbal treatment of allergic rhinitis: the use of Nigella sativa, Am J Otolaryngol, 32(5), 2011, 402-7.

28. Burits M, Bucar F, Antioxidant activity of Nigella sativa essential oil, Phytotherapy research, 14(5), 2000, 323-8.

29. Sahebkar A, Beccuti G, Simental-Mendía LE, Nobili V, Bo S, Nigella sativa (black seed) effects on plasma lipid concentrations in humans: $A$ systematic review and meta-analysis of randomized placebo-controlled trials, Pharmacol Res, 106, 2016, 37-50.

30. Al-Ghasham A, Ata HS, El-Deep S, Abdel-Raheim Meki, Shehada S, Study of protective effect of date and Nigella sativa on Alfatoxin $B_{1}$ toxicity, Int J Health Sci (Qassim), 2(2), 2008, 26-44.

31. Ebrahim M Yimer, KaldBeshirTuem, Aman Karim, Najeeb Ur Rehman, Farooq Anwar, Nigella sativa L. (Black Cumin): A promising Natural Remedy for Wide range of Illnesses, Evidence based Complementary and Alternative Medicine, Article ID 1528635, 2019.

32. Morris DH (2007) Flax-a health and nutrition primer, 4th edn. Available from: www.flaxcouncil.ca

33. Rubilar M, Gutiérrez $C$, Verdugo $M$, Shene $C$, Sineiro J, Flaxseed as a source of functional ingredients, J Soil Sci Plant Nutr, 10, 2010, 373-377.

34. Singh KK, Jhamb SA, Kumar R, Effect of pretreatments on performance of screw pressing for flaxseed, J Food Pocess Eng, 2011.

35. Oomah BD, Flaxseed as a functional food source, J Sci Food Agric, 81, 2001, 889-894.

36. Shakir KAF, Madhusudan B, Hypocholesterolemic and hepatoprotective effects of flaxseed chutney: evidence from animal studies, Int J Clin Biochem, 22, 2007, 117-121.

37. Toure A, Xueming X, Flaxseed lignans: source, biosynthesis, metabolism, antioxidant activity, bio-active components and health benefits, Compr Rev Food Sci Food Saf, 9, 2010, 261-269.

38. Carter JF, Potential of flaxseeds and flaxseed oil in baked goods and other products in human nutrition, Cereal Foods World, 38, 1993, 754759.

39. Payne TJ, "Promoting better health with flaxseed in bread", Cereal Foods World 45(3), 2000, 102-104.

40. Mueller K, Eisner P, Yoshie-Stark Y, Nakada R, Kirchoff E, "Functional properties and chemical composition of fractionated brown and yellow linseed meal (Linum usitatissimum L.)"', J Food Eng 98, 2010, 453-460.

41. Rabetafika HN, Remoortel VV, Danthine S, Paquot M, Blecker C, "Flaxseed proteins: food uses and health benefits". Int J Food Sci Technol 46, 2011, 221-228.

42. Madhusudan KT, Singh N. "Isolation and characterization of major protein fraction (12 S) of flaxseed proteins", J Agric Food Chem 33, 1985, 673-677.

43. Oomah BD, Mazza G, "Flaxseed proteins-a review". Food Chem, 48, 1993, 109-114.

44. Oomah BD, Mazza G, "Effect of dehulling on chemical composition and physical properties of flaxseed", Lebensm Wiss Technol 30, 1997, 135-140

45. Oomah BD, Mazza G, "Compositional changes during commercial processing of flaxseed". Ind Crop Prod 9, 1998, 29-37.

46. Xu Y, Hall C III, Wolf-Hall C, "Antifungal activity stability of flaxseed protein extracts using response surface methodology", J Food Sci 73, 2008a, M9-M14

47. Xu Y, Hall C III, Wolf-Hall C. "Antifungal activity stability of flaxseed protein extracts using response surface methodology", Food Microbiol Saf 73, 2008b, M9-M14.

48. Morris MC, Evans DA, Tangney CC, Relation of the tocopherol forms to incident alzheimer disease and to cognitive change, Am J Clin Nutr, 81, 2005, 508-514. 
49. Chang CC, Yang MH, Wen HM, Chern JC, Estimation of total flavaniod content in propolis by two complementary colorimetric methods, Journal of Food and Drug Analysis, 10, 2002, 178-182.

50. Sarabjot Kaur, Poonam Monda, Study of Total Phenolic and Flavonoid Content, Antioxidant Activity and Antimicrobial Properties of Medicinal Plants, Journal of Microbiology \& Experimentation, 1(1), 2014.

51. Panche AN, Diwan AD, Chandra SR, Flavonoids: an overview, Journal of Nutrition Science, 5:e47, 2016.

52. Daglia M, Polyphenols as antimicrobial agents, Current Opinion in Biotechnology, 23, 2012, 174-181.
53. Foti MC, Antioxidant properties of phenols, J Pharm Pharmacol, 59(12), 2007, 1673-85.

54. López-Alarcón C, Denicola A, Evaluating the antioxidant capacity of natural products: a review on chemical and cellular-based assays, Analytica Chimica Acta, 763, 2013, 1-10.

55. Ostrea Enrique M, Cepeda Eugene E, Fleury Cheryl A, Balun James E, "Red Cell Membrane Lipid Peroxidation and Hemolysis Secondary to Phototherapy", Acta Paediatrica, 74(3), 1985, 378-381.

56. Marnett $\sqcup$ "Lipid peroxidation-DNA damage by malondialdehyde", Mutation Research, 424 (1-2), 1999, 83-95.

Source of Support: None declared.
Conflict of Interest: None declared.

For any question relates to this article, please reach us at: editor@globalresearchonline.net

New manuscripts for publication can be submitted at: submit@globalresearchonline.net and submit_ijpsrr@rediffmail.com 